\title{
Sustainability in Project Management Practice
}

\author{
A ghaegbuna Ozumba ${ }^{1 *}$, Tasmiyah Chothia ${ }^{1}$, Zanoxolo Booi ${ }^{1}$ and Nikiwe Madonsela ${ }^{1}$ \\ 1 University of the W itwatersrand, 1 J an Smuts A ve, J ohannesburg 2000, South A frica
}

\begin{abstract}
The study focused on the application of sustainability in project management, with reference to attendant difficulties experienced, which affect the goal of achieving sustainability outcomes in project management. As such the study explored the nature and occurrence of challenges to the integration of sustainability principles with PM practice. A review of purposively sampled literature was complemented with fieldwork, which involved an online questionnaire with eighty-nine participants, to collect qualitative data, using South A frica as context. The major limitation was the purposive use of professional project managers as a sample population. The findings reveal that project managers experience significant challenges when implementing sustainability in their practice. While confirming deductions from the literature review, findings suggest that the most significant challenge may be the lack of information among participants and other stakeholders. One major implication is that other identified difficulties may be traceable to the same lack of knowledge in the subject area. Identified consequences include delayed projects and complete abandonment of the sustainability principles in projects. The integration of sustainability principles with project management practice is a growing niche area of project management knowledge. The study contributes a unique exploration of nature and occurrence, and dynamics of attendant challenges, through a comparison of experience and perception. The comparison has highlighted the differences between the experience and perception of project managers, with reference to the application of sustainability principles.
\end{abstract}

Keywords: challenges, knowledge, practice, project management, sustainability

\section{Introduction}

The research interest here is the apparent challenge faced by project managers in practising sustainable construction. Essentially the challenges faced when incorporating the relevant sustainability principles in project management (PM) practice. Sustainability is the general principle of a balanced approach to development which considers the three-fold perspective of the environment, people, and the economy [1]. The increasing global sensitivity towards sustainability has resulted in the effort by industries to research and establish effective

* Corresponding author: Obinna.Ozumba@ wits.ac.za 
methods to incorporate the relevant principles in their processes [2]. The built environment is a major contributor to economy and employment, which also has a profound negative impact on the people, and the biophysical environment. In view of the implications, the construction industry has made efforts to incorporate sustainability into design, procurement, and construction processes [3]. The growing interest in applying sustainability in construction projects has been reported in the literature such as Kivilä et al. [4]. There is also evidence in the literature, of the growing discourse and efforts in the application of sustainability to construction project management such as $\mathrm{Yu}$ et al. [5], Doskočil and Lacko [6] and Zavadskas et al. [7]. Since construction runs by projects, it follows that relevant sustainability principles would have to be integrated with project management practice, to achieve the aim. According to Bocchini et al. [8], this is a means to positively introduce sustainability in construction projects. Marcelino-Sádabaa et al. [2] had proposed PM as a largely unexploited vehicle for the achievement of sustainability.

\section{Sustainability and Project Management}

By nature, sustainability is focused on the long-term view of any situation, seeking to integrate the social, environmental and economic aspects of a project. Conversely, PM is focused on the project duration, seeking to achieve the desired time, cost and quality specifications of the project. However, according to Silvius et al. [9] the application of sustainability in PM considers the whole life-cycle of the project. It is also suspected that the integration of economic, environmental and social aspects in the management of projects may occasion changes in the project management profession. Project managers (PMs) are said to be concerned that such integration will affect project management practices and project managers' competencies [10]. In addition, Silvius, et al. [9] notes that the failure of PM standards to address sustainability in terms of competency makes it difficult to apply sustainability in projects. Misopoulos et al. [11] with a focus on the manufacturing industry highlights the lack of holistic approaches which do not factor in the systemic and institutional issues. Kivilä et al. [4] further support the need for a holistic approach to achieve sustainable project goals. It has also been reported that while there is more focus on sustainability in projects by PMs, there is a gap between what they perceive as important and the practical application [12].

From the multi-dimensional systemic view of sustainability, the need should be to achieve environmental, economic and social sustainability from project outcomes. As such, there is a need to integrate sustainability in all its ramifications, into the functions, roles, and responsibilities of project managers. However, attempts at achieving such integration in many countries have been known to face challenges [3]. It has been said that sustainability dimensions/principles are difficult to incorporate into construction programmes and projects. However, there is insufficient information in the area of challenges, especially empirical studies. Marcelino-Sádaba et al. [2] highlight the scarcity of relevant information. Silvius et al. [28] acknowledge the growing momentum in research around sustainability in project management. The authors also highlight the need for more empirical research. Yu et al. [5] also highlight the lack of project-level focus in the design of evaluation systems for sustainability in projects. Marcelino-Sádaba et al. [2] further assert that more progress has been made in the environmental focus of relevant research, than the social aspect, which would be the domain for PM. Generally, extant literature, for the most part, is focused on issues such as analysing key aspects of sustainability projects [6]; introduction of management systems [13]; PM commitment to sustainability [14]; sustainability assessment [7]; Project sustainability performance [15]; technology, Materials, risk, and cost [7]; Design [7, 16, 17]; Critical success factors [18]; stakeholders, organisational goals [19]; and innovation diffusion $[18,20]$. Most existing studies do not present a concise picture 
of the nature and occurrence of challenges, for better classifications and articulation of the dynamics, with regards to PM practice, and from the experiences and perceptions of PMs. Thus the pertinent research question is:

What is the nature and occurrence of challenges to the integration of sustainability principles with PM practice? Based on the foregoing, it would be necessary to understand the factors which threaten the integration of sustainability principles with PM practice, especially from the views of PMs. The research aim can then be stated as: To determine the nature and occurrence of challenges to the integration of sustainability principles with PM practice, the dynamics if any, in relation to PM practice, from the views of PMs. The current study attempts to explore this gap area, starting with a review of extant literature, which is complemented with the analysis of field data.

\subsection{Challenges to Project Managers' application of Sustainability Principles}

A review of relevant literature on the topic was conducted. The following categories were derived from literature review findings: Planning-related challenges, project-related challenges, client-related challenges, project team-related challenges, labour-related challenges, and external challenges. For the purpose of this paper, this section summarises findings on challenges faced by project managers when applying sustainability principles in project management, citing key references. They are described in more detail, hereunder, using key literature sources for the above-mentioned challenges.

\section{Planning-related challenges}

Individual Challenges identified under this heading from extant literature are: Adoption of different contract forms of project delivery; the design, orientation and structure of the building; planning of different construction sequence; planning of different construction technique; lengthy approval process for new green technologies within the organization; longer time required during the pre-construction process; and difficulty in comprehending the green specifications in the contract details. It is noteworthy that challenges identified under this heading relate more to the organisational environment.

\section{Project-related challenges}

Challenges identified under this heading from extant literature are: Difficulty in approving payment disbursement to suppliers and subcontractors; difficulty in assessing the progress of completion in green construction; difficulty in the selection of subcontractors in providing green construction service; more time is required to implement green construction practices onsite; and more alteration and variation with the design during the construction process.

\section{Client-related challenges}

Challenges identified under this heading from extant literature are: Specific budget specification of the green project; the objective of the building project; required date of completion; the level of risk the client is willing to take on green technologies; the client uses a lot of time in making a decision; and a special request from client pertaining to specified green technologies to be used. 


\section{Project team-related challenges}

Challenges identified under this heading from extant literature are: Conflict with the architect over the type of material to be used; lack of communication and interest among project team members; frequent meetings with green specialists; green consultant delay in providing information; conflict of interest between consultant and project manager; specific performance required for green building projects; material and equipment -related challenges; high cost in green material and equipment; uncertainty with green material and equipment; availability of green material and equipment; decision on different green material and equipment; imported green material or equipment.

\section{Labour -related challenges}

Challenges identified under this heading from extant literature are: Resistance to change from their traditional practices; lack of the technical skill regarding green technologies and techniques; workers' unaware of the correct methods and procedures.

\section{External challenges}

Challenges identified under this heading from extant literature are: Government policy; the lengthy body of standards' approval process for new technologies; and unforeseen circumstances in a green project $[9,10,21,22-26]$.

Considering the categories and individual challenges, it is noteworthy that while some challenges are grouped under external and labour-related, the PM and client role players, seem to have the most influence. Essentially, most of the threats to the application of sustainability in PM are related to planning, the project, the project team, and the client. There is an appreciable effort in the existing literature to explore project managers and client on the topic of integrating sustainability with PM. Most authors have focused generally on the diffusion of sustainability principles in PM practice. Other authors have looked at the compatibility of principles from sustainability and PM, and standards and competency issues. Thus, while some explorations of the specific perspective on project managers' experiences have begun, there is still an appreciable gap in this area. In addition, there seems to be a dearth of information regarding such issues, in writings that are specifically focused on emerging economies/developing countries of the world. Few authors have looked at the specific perspective of project managers experiences, within developing country contexts. This perspective is pertinent as developing countries are known to be facing strains from the demands for development and construction, and constrained economies, with the emergent need for higher sustainability in projects.

Martens and Carvello [12], note that PM is already inherent in construction projects. As such the incorporation of sustainability will generate difficulties due to conflicts of objectives, and knowledge gaps. It is therefore arguable that the achievement of sustainability in projects constitutes additional responsibility for PMs generally. It is further argued that the situation would be even more so for PMs in developing countries such as South Africa.

In the context of South Africa, there are some landmark events which highlight efforts to improve sustainability in construction. There are legislations such as the SANS 204 [27], which provides guidelines for energy efficiency in buildings. There is the green building council of South Africa which currently advocates sustainable construction through their green building rating system. There is also an increase in research, however, there is still a knowledge gap in the specific aspect of project managers' application of sustainability in their practice. 
Hence the current study attempts to establish an additional understanding of the dynamics, by specifically comparing experiences with perceptions, and exploring other constructs such as the consequences. The comparison of experiences and perceptions of PMs provide insight into the influence of identified challenges in terms of their impact, and the response of PMs to their occurrence and perceived existence. The research design presented hereunder was purposed to collect primary data for the current study.

\section{Research Design for the study}

This research starts from a positivist view, based on available information on the topic. However, the specific focus required an exploratory/inductive reasoning approach to finally collect and analyse qualitative data. Filed work questions were formulated based on literature review findings. A cross-sectional survey strategy was used through an online questionnaire, sent to a sample of construction and project managers. The participants were registered with the South African Council for Project and Construction Management Professions (SACPCMP). Participants were invited through the council's official mailing system, while completed responses were only accessible to the authors. A semi-structured questionnaire with a combination of closed and open-ended questions was designed through the Qualtrics online survey system. Responses were retrieved in September 2016. Issues of validity and reliability were addressed by analysing and testing the instruments and assessing the response magnitude (130), and completeness of responses. Ethical issues adhered to include anonymity, confidentiality, informed consent, and voluntary participation.

\subsection{Findings}

A total of (130) responses were received. About (32\%), 41 responses were incomplete and therefore discarded, leaving (89) usable responses. Project managers with experience in sustainable construction projects numbered $55(62 \%)$ out of the 89 responses, while those without experience in sustainable construction made up the remaining (38\%) 34 responses. This diversity provided rich data as participants were asked to provide answers according to what they have experienced (for those who had experience with sustainable construction) and what they perceive to be experienced (for those who have only experienced conventional projects). Other constructs were explored in the study. However, for the purpose of this paper, 'challenges' are presented, from the results of preliminary qualitative analysis, aimed at achieving a description.

\section{General Ranking of Challenges Experienced and Perceived}

Respondents indicated and ranked challenges according to their experience and perception respectively. Table 1 summarizes and ranks the results according to the challenges (perceived and experienced) by project and construction managers.

Table 1. Challenges Experience and Perceived

\begin{tabular}{|c|c|c|}
\hline Ranks & Experienced Challenges & Perceived Challenges \\
\hline 1 & $\begin{array}{l}\text { Meeting the objectives within the defined } \\
\text { budget. }\end{array}$ & Increased costs of materials and equipment. \\
\hline 2 & $\begin{array}{c}\text { Increased costs of materials and } \\
\text { equipment. }\end{array}$ & $\begin{array}{l}\text { Meeting the objectives within the defined } \\
\text { budget. }\end{array}$ \\
\hline 3 & $\begin{array}{l}\text { Meeting the objectives within the defined } \\
\text { time. }\end{array}$ & Increased level of risk involved. \\
\hline
\end{tabular}




\begin{tabular}{|c|c|c|}
\hline 4 & Incorporation of new technologies. & $\begin{array}{l}\text { More alterations and variations with the } \\
\text { design. }\end{array}$ \\
\hline 5 & Communication between stakeholders. & $\begin{array}{c}\text { Meeting the objectives within the defined } \\
\text { time. }\end{array}$ \\
\hline 6 & $\begin{array}{l}\text { Selection of subcontractors in providing } \\
\text { green construction service. }\end{array}$ & Communication between stakeholders. \\
\hline 7 & Increased level of risk involved. & $\begin{array}{c}\text { Planning of different construction } \\
\text { technique. }\end{array}$ \\
\hline 8 & $\begin{array}{l}\text { Specific performance required for green } \\
\text { building projects. }\end{array}$ & $\begin{array}{l}\text { Comprehending specifications with the } \\
\text { contract. }\end{array}$ \\
\hline 9 & $\begin{array}{c}\text { Planning of different construction } \\
\text { technique. }\end{array}$ & $\begin{array}{l}\text { Selection of subcontractors in providing } \\
\text { green construction service. }\end{array}$ \\
\hline 10 & $\begin{array}{l}\text { More alterations and variations with the } \\
\text { design. }\end{array}$ & $\begin{array}{c}\text { Specific performance required for green } \\
\text { building projects }\end{array}$ \\
\hline 11 & $\begin{array}{l}\text { Availability and uncertainty of the } \\
\text { materials and the equipment. }\end{array}$ & Incorporation of new technologies. \\
\hline 12 & Conflicts with project team members. & $\begin{array}{l}\text { Meeting the objectives within the defined } \\
\text { quality. }\end{array}$ \\
\hline 13 & $\begin{array}{c}\text { Increased involvement of project team } \\
\text { members. }\end{array}$ & $\begin{array}{l}\text { Availability and uncertainty of the materials } \\
\text { and the equipment. }\end{array}$ \\
\hline 14 & $\begin{array}{l}\text { Incorporation of standards, regulations } \\
\text { and legislation. }\end{array}$ & Conflicts with project team members. \\
\hline 15 & $\begin{array}{l}\text { Meeting the objectives within the defined } \\
\text { quality. }\end{array}$ & $\begin{array}{c}\text { Increased involvement of project team } \\
\text { members. }\end{array}$ \\
\hline 16 & $\begin{array}{l}\text { Comprehending specifications with the } \\
\text { contract. }\end{array}$ & $\begin{array}{c}\text { Incorporation of standards, regulations and } \\
\text { legislation. }\end{array}$ \\
\hline 17 & $\begin{array}{l}\text { Green consultant delay in providing } \\
\text { information. }\end{array}$ & $\begin{array}{l}\text { Adoption of different contract forms for } \\
\text { project delivery. }\end{array}$ \\
\hline 18 & $\begin{array}{l}\text { Adoption of different contract forms for } \\
\text { project delivery. }\end{array}$ & $\begin{array}{l}\text { Green consultant delay in providing } \\
\text { information. }\end{array}$ \\
\hline
\end{tabular}

All challenges identified from the literature were indicated by the two respondent groups. The inexperienced respondent group saw 'increased costs of materials and equipment', as the top-ranking challenge, followed by 'meeting the objectives within the defined budget', and the 'increased level of risk involved'. Experienced respondents viewed the 'achievement of objectives within defined budget', as top ranking, followed by increased costs of materials and equipment, meeting the objectives within the defined time, and the incorporation of new technologies.

\section{Challenges according to Project Stages}

Considering project lifecycle phases, respondents' indications (perceived/experienced) sit generally between the design development (stage 3) and construction and contract administration (stage 5). Stage 5 also seems to have the most number of challenges. Experienced participants indicated a ranking order of stages 5, 3, 4, etc. In contrast, inexperienced participants perceive the order of stages 5, 4, 3, etc. This ranking is according to the prevalence of challenges at respective project stages. See Table 2. 
Table 2. Challenges Experience and Perceived

\begin{tabular}{|c|c|c|c|}
\hline Stages & $\begin{array}{l}\text { Ra } \\
\text { nks }\end{array}$ & Challenges Experienced in projects & $\begin{array}{c}\text { Challenges Perceived as occurring in } \\
\text { projects }\end{array}$ \\
\hline \multirow{3}{*}{$\begin{array}{c}\text { Stage 1 } \\
\text { - Project } \\
\text { initiatio } \\
n \\
\text { and } \\
\text { briefing }\end{array}$} & 1 & Communication between stakeholders. & Communication between stakeholders. \\
\hline & 2 & $\begin{array}{l}\text { Increased involvement of project team } \\
\text { members. }\end{array}$ & $\begin{array}{l}\text { Increased involvement of project team } \\
\text { members. }\end{array}$ \\
\hline & 3 & $\begin{array}{l}\text { Meeting the objectives within the } \\
\text { defined quality. }\end{array}$ & $\begin{array}{l}\text { Green consultant delay in providing } \\
\text { information. }\end{array}$ \\
\hline \multirow{3}{*}{$\begin{array}{c}\text { Stage } 2 \\
- \\
\text { Concept } \\
\text { and } \\
\text { viability }\end{array}$} & 1 & Communication between stakeholders. & Communication between stakeholders. \\
\hline & 2 & $\begin{array}{l}\text { Green consultant delay in providing } \\
\text { information. }\end{array}$ & Conflicts with project team members. \\
\hline & 3 & $\begin{array}{c}\begin{array}{c}\text { Increased involvement of project team } \\
\text { members. }\end{array} \\
\end{array}$ & $\begin{array}{c}\text { Incorporation of standards, regulations } \\
\text { and legislation. }\end{array}$ \\
\hline \multirow{3}{*}{$\begin{array}{c}\text { Stage } 3 \\
\text { - Design } \\
\text { develop } \\
\text { ment }\end{array}$} & 1 & $\begin{array}{l}\text { Green consultant delay in providing } \\
\text { information. }\end{array}$ & $\begin{array}{c}\text { Incorporation of standards, regulations } \\
\text { and legislation. }\end{array}$ \\
\hline & 2 & Communication between stakeholders. & $\begin{array}{l}\text { Green consultant delay in providing } \\
\text { information. }\end{array}$ \\
\hline & 3 & $\begin{array}{l}\text { Incorporation of standards, regulations } \\
\text { and legislation. }\end{array}$ & $\begin{array}{l}\text { Increased involvement of project team } \\
\text { members. }\end{array}$ \\
\hline \multirow{3}{*}{$\begin{array}{c}\text { Stage } 4 \\
\text { - Tender } \\
\text { docume } \\
\text { ntation } \\
\text { and } \\
\text { procure } \\
\text { ment } \\
\end{array}$} & 1 & $\begin{array}{l}\text { Selection of subcontractors in } \\
\text { providing green construction service. }\end{array}$ & $\begin{array}{l}\text { Comprehending specifications with } \\
\text { the contract. }\end{array}$ \\
\hline & 2 & $\begin{array}{l}\text { Comprehending specifications with } \\
\text { the contract. }\end{array}$ & $\begin{array}{l}\text { Adoption of different contract forms } \\
\text { for project delivery. }\end{array}$ \\
\hline & 3 & $\begin{array}{l}\text { Adoption of different contract forms } \\
\text { for project delivery. }\end{array}$ & $\begin{array}{l}\text { Selection of subcontractors in } \\
\text { providing green construction service. }\end{array}$ \\
\hline \multirow{3}{*}{$\begin{array}{c}\text { Stage } 5 \\
- \\
\text { Constru } \\
\text { ction } \\
\text { and } \\
\text { contract } \\
\text { adminis } \\
\text { tration }\end{array}$} & 1 & $\begin{array}{l}\text { Meeting the objectives within the } \\
\text { defined time. }\end{array}$ & $\begin{array}{l}\text { Meeting the objectives within the } \\
\text { defined time. }\end{array}$ \\
\hline & 2 & $\begin{array}{l}\text { More alterations and variations with } \\
\text { the design. }\end{array}$ & $\begin{array}{l}\text { Meeting the objectives within the } \\
\text { defined quality. }\end{array}$ \\
\hline & 3 & $\begin{array}{c}\text { Increased costs of materials and } \\
\text { equipment. }\end{array}$ & $\begin{array}{c}\text { Increased costs of materials and } \\
\text { equipment. }\end{array}$ \\
\hline \multirow{3}{*}{$\begin{array}{c}\text { Stage } 6 \\
\text { - Project } \\
\text { closeout }\end{array}$} & 1 & $\begin{array}{l}\text { Increased involvement of project team } \\
\text { members. }\end{array}$ & Communication between stakeholders. \\
\hline & 2 & $\begin{array}{c}\text { Incorporation of standards, regulations } \\
\text { and legislation. }\end{array}$ & $\begin{array}{l}\text { Meeting the objectives within the } \\
\text { defined quality. }\end{array}$ \\
\hline & 3 & Communication between stakeholders. & $\begin{array}{c}\text { Meeting the objectives within the } \\
\text { defined time. }\end{array}$ \\
\hline
\end{tabular}




\section{Prevalence of Identified Challenges}

With regards to prevalence according to the rate of occurrence, the following key was used (seldom, moderate and often). Experienced respondents indicated most of the challenges as often occurring, while inexperienced respondents perceived a moderate rate of occurrence for most challenges. Both groups indicated differently in terms of ranking of prevalence, though they agree on the top-ranked "Meeting the objectives within the defined budget". See Table 3 .

Table 3. Frequency of Challenges Experience and Perceived

\begin{tabular}{|c|c|c|}
\hline $\begin{array}{c}\text { Rank } \\
\text { ing }\end{array}$ & Experienced Challenges & Perceived Challenges \\
\hline 1 & $\begin{array}{l}\text { Meeting the objectives within the defined } \\
\text { budget. }\end{array}$ & $\begin{array}{l}\text { Meeting the objectives within the defined } \\
\text { time. }\end{array}$ \\
\hline 2 & $\begin{array}{l}\text { More alterations and variations with the } \\
\text { design. }\end{array}$ & $\begin{array}{l}\text { Green consultant delay in providing } \\
\text { information. }\end{array}$ \\
\hline 3 & Communication between stakeholders. & $\begin{array}{c}\text { Incorporation of standards, regulations and } \\
\text { legislation. }\end{array}$ \\
\hline 4 & Increased costs of materials and equipment. & Increased costs of materials and equipment. \\
\hline 5 & Increased level of risk involved. & $\begin{array}{c}\text { Comprehending specifications with the } \\
\text { contract. }\end{array}$ \\
\hline 6 & $\begin{array}{c}\text { Meeting the objectives within the defined } \\
\text { time. }\end{array}$ & $\begin{array}{l}\text { Meeting the objectives within the defined } \\
\text { budget. }\end{array}$ \\
\hline 7 & $\begin{array}{l}\text { Comprehending specifications with the } \\
\text { contract. }\end{array}$ & $\begin{array}{l}\text { More alterations and variations with the } \\
\text { design. }\end{array}$ \\
\hline 8 & $\begin{array}{l}\text { Selection of subcontractors in providing } \\
\text { green construction service. }\end{array}$ & Communication between stakeholders. \\
\hline 9 & $\begin{array}{c}\text { Increased involvement of project team } \\
\text { members. }\end{array}$ & $\begin{array}{c}\text { Specific performance required for green } \\
\text { building projects. }\end{array}$ \\
\hline 10 & $\begin{array}{c}\text { Incorporation of standards, regulations and } \\
\text { legislation. }\end{array}$ & $\begin{array}{c}\text { Selection of subcontractors in providing } \\
\text { green construction service. }\end{array}$ \\
\hline 11 & Conflicts with project team members. & $\begin{array}{c}\text { Increased involvement of project team } \\
\text { members. }\end{array}$ \\
\hline 12 & $\begin{array}{l}\text { Meeting the objectives within the defined } \\
\text { quality. }\end{array}$ & $\begin{array}{c}\text { Availability and uncertainty of the } \\
\text { materials and the equipment. }\end{array}$ \\
\hline 13 & Incorporation of new technologies. & $\begin{array}{l}\text { Meeting the objectives within the defined } \\
\text { quality. }\end{array}$ \\
\hline 14 & $\begin{array}{c}\text { Specific performance required for green } \\
\text { building projects. }\end{array}$ & Increased level of risk involved. \\
\hline 15 & $\begin{array}{c}\text { Planning of different construction } \\
\text { technique. }\end{array}$ & $\begin{array}{l}\text { Planning of different construction } \\
\text { technique. }\end{array}$ \\
\hline 16 & $\begin{array}{l}\text { Adoption of different contract forms for } \\
\text { project delivery. }\end{array}$ & Incorporation of new technologies. \\
\hline 17 & $\begin{array}{l}\text { Availability and uncertainty of the } \\
\text { materials and the equipment. }\end{array}$ & Conflicts with project team members. \\
\hline 18 & $\begin{array}{l}\text { Green consultant delay in providing } \\
\text { information. }\end{array}$ & $\begin{array}{l}\text { Adoption of different contract forms for } \\
\text { project delivery. }\end{array}$ \\
\hline
\end{tabular}




\section{Significance of Identified Challenges}

Following the five categories derived from analysis of literature review findings, participants were asked to rate their relative significance. The questionnaires were given in a five-point Likert type scale (from [5] - extremely challenging, to [1] - not challenging at all). According to experienced participants, the challenges range from moderately challenging to extremely challenging. See Figure 1.

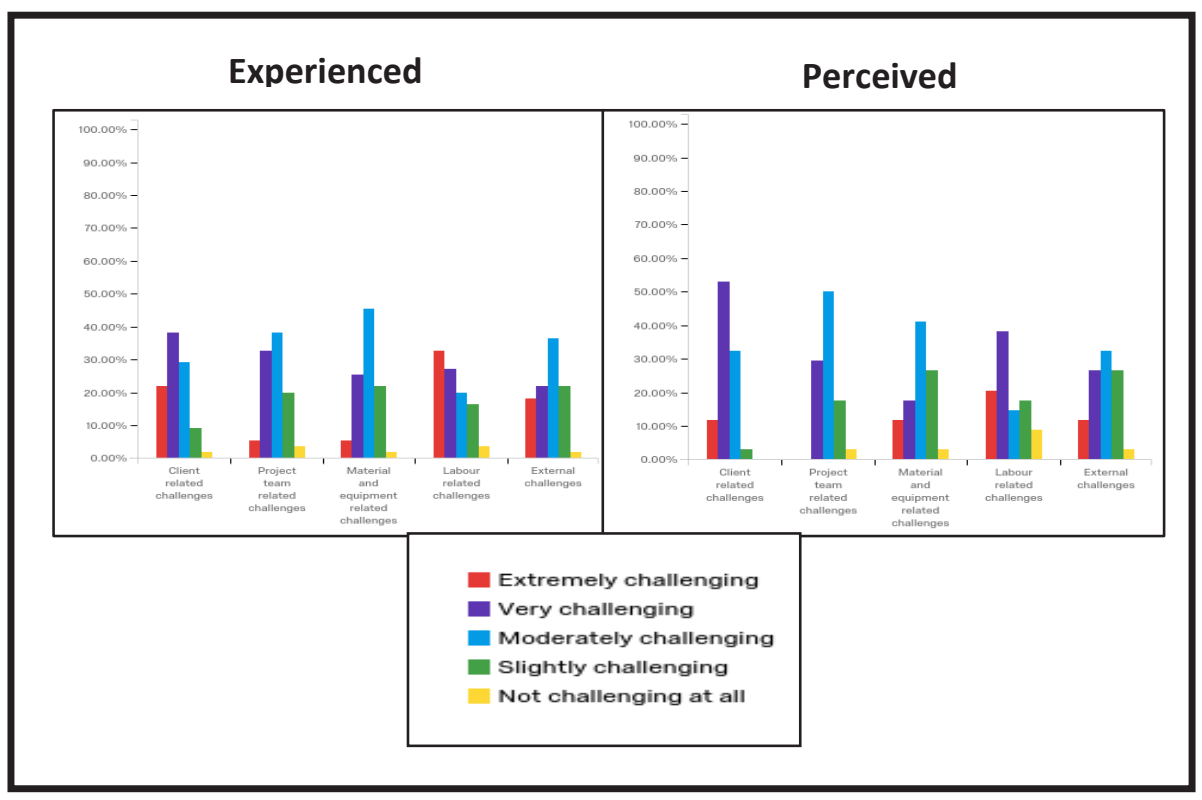

Figure 1. Comparison of the significance of identified Challenges

Labour-related challenges were ranked as the most significant factors. Client related challenges were very challenging. The rest were moderately challenging. Inexperienced respondents perceived a shorter spectrum, which ranged between moderately challenging and very challenging. They also highlighted client and labour related challenges as being very challenging. Project team challenges, material and equipment related challenges, and external challenges were perceived as being moderately challenging.

\subsection{Discussion}

Firstly, from the results presented thus far, there is a suggestion of strong correspondence with literature review findings. Secondly results of analysis highlight labour issues as topranking amongst the extremely challenging factors. However, among researchers, the economic factors remain the most critical and the main challenge when integrating sustainability into construction project management. The survey result, however, suggests that major costs result mostly from a lack of knowledge about sustainability principles and their application. Thirdly there seems to be a lack of knowledge and experience among stakeholders within sustainable projects. This knowledge gap seems to manifest as incompetence by project managers which contributes to difficulties encountered. Another major source of difficulties is poor implementation of processes and financial feasibility of sustainable projects, which could be indirectly linked to knowledge-related issues. Consequently, there are project delays, cost increases, quality compromises and poor 
working relationships. Poor implementation of the process is arguably traceable to a lack of knowledge among project managers and other stakeholders.

In addition, one of the major challenges to South African construction industry growth is the high cost of construction materials. However, regarding sustainable construction, Akadiri [26] asserts the existence of misperceptions about the costs of sustainable materials. The same notions were noted in the current study. From other evidence gathered during the study, it was deduced that poor perceptions of sustainable project management, and inadequate understanding of the full spectrum of associated costs, constitute a major part of the knowledge-related issues. Gaps in the demonstrated understanding of important issues around the application of sustainability by project managers were also suggested in Martens and Carvalho [12]. Without clear evaluation systems for sustainability at the project level, as noted by Yu et al. [5], there is very little check and balances that highlight the knowledgerelated gaps. Also, Marly et al. [17] emphasised the knowledge gap between ecological/sustainable design and project management, in the area of product development. The need for Project management guidelines was also highlighted. These assertions point more at knowledge-related factors.

About $(83 \%)$ of respondents agreed that project and construction managers need specified skills and knowledge beyond the PMBoK to effectively deliver sustainability goals in projects. Most respondents also see the integration of sustainability and PM as 'the comparison of the incomparable', which speaks to the conflicts of principles highlighted in Silvius and Schipper's [10]. Such conflicts would also emanate from organisational factors, which manifest as institutional and systemic challenges, as suggested by Misopoulos et al. [11]. Some respondents specifically highlight these conflicts and demonstrate discomfort in relation to the question. They also hint at the natural reaction of generating a coping mechanism when there is a perceived lack of capacity or difficulty:

Conflicting specifications and goals. At best difficult to achieve financial and project goals with sustainability. You have to mix the negatives with the positives and be content with what you get.

There is a moderate level of alignment between experienced and perceived difficulties, from the survey result. However, there are some less subtle misalignments, of which the seven most significant relate to quality, risks involved in projects, contracts, materials and equipment, and incorporation of new technologies and design variations. There are also clear misalignments with then two groups of responses, in timing the occurrence of some challenges. Such clear misalignments suggest knowledge gaps ultimately. This will occasion inadequacy in current approaches because the full spectrum of relevant issues may not be factored into PM planning and execution. The need for a holistic approach to sustainability in project management was highlighted in Silvius et al. [28]; Kivilä et al. [4].

In the context of South Africa, the existing preferential procurement environment acts as a challenge to industry growth because it forces stakeholder selection based on factors other than quality and competence. In the context of sustainable construction, this situation would increase the risk of failure and therefore act as a major deterrent towards the integration of sustainability principles. Some respondents in the current study identified certain factors as external and beyond the immediate environment of PMs and stakeholders. In response to the question of the consequences of applying sustainability to PM, some respondents answered:

Taxpayer will be held responsible in case of failure! As well BEE policies occur into the failure of the project (qualifications are not existent). 
We end up with projects with long term environmental impacts.

The said BEE policies refer to preferential procurement policies aimed at empowering local companies that are owned by people of African descent. From the responses, it is evident that in the case of failure; people who had no contribution and sometimes even knowledge of such projects happen to be the ones held responsible. The use of an exclamation indicates an emotion that is related to the question. It could also hint at a point of frustration. The second response highlights the inevitable negative consequences, which become long term negative influence on the environment. Preferential procurement has been strongly linked to the failure of such projects, which again suggests issues of knowledge and competence.

\section{Conclusions}

The current study explored the difficulties experienced by project managers when sustainability principles are applied in PM. The effect of this integration on the dual goals of achieving sustainability and project success within the South African construction industry was explored. Purposively selected literature was used for secondary data while an online survey strategy was used for primary data. While various constructs were explored in the survey, the focus of the current paper is challenging. Although the analysis was conducted at various levels, only results of the descriptive analysis were presented in the current paper.

Limitations in the study relate to purposive sampling, nature of survey response, and completeness of responses. Though over $(30 \%)$ of the (130) retrieved responses were discarded, the remaining (89) complete responses amounted to an appreciable numerical strength, which allowed for rich comparison between two groups of data. In addition, the agreement of the results with extant literature sampled globally lends a measure of strength to the results in terms of generalisability beyond South Africa, at least to similar developing country contexts. Following the findings from data analysis and the subsequent discussion of the findings with extant literature, the guiding research question stated earlier can be addressed hereunder.

With regards to the nature and occurrence of challenges, there is a strong similarity with extant literature. The overarching deduction at this stage is a strong suggestion that the challenges may be largely traceable to gaps in knowledge among project managers and other project stakeholders. It is however in the indicated patterns of occurrence that various dynamics are highlighted. Such differences relate more to the unique nature of the analysis in the current paper. The uniqueness refers to the comparison of experience with perception, of the respondents. While the respondents generally agree on the existence of all challenges explored, there are clear areas of disagreement for seven of the identified challenges. Further on the dynamics, the occurrence of challenges differed by views of respondent groups, project stages, and prevalence. Similarly, the extent of consequences from the challenges ranged from delayed projects to complete abandonment of the sustainability principles. Furthermore, there is an appreciable level of discomfort/concern with the notion of integrating sustainability with PM, among respondents generally. Moreover, the differences between the views of experienced and inexperienced PMs with regard to sustainable construction ranged between subtle and strong. The function of knowledge in the outcomes derived from the current paper is highly suggested.

Arguably the current study brings a unique perspective to the growing area of research, which is sustainability in project management. While there is limited information on the challenges of integrating sustainability in PM practice, there is even more scarcity of literature exploring dynamics related to experiences and perceptions of PMs. The uniqueness refers to the comparison of experience-based assessment with views based 
on people's perception of the probable nature and occurrence of the relevant challenges. Thus, a stronger basis has been achieved, for future extrapolations, analysis and articulation of findings from future studies. Essentially the current study contributes new material, with a focus on threats to the integration of sustainability in project management practice, as opposed to most studies which focus more on diffusion generally. The current study also brings new insights to the study area by highlighting the emerging dynamics in actual experiences/observations vs. perceptions of nature and occurrence thereof.

Appreciable conjectures have been drawn at this stage of the study. There is however a need to further explore the highlights and the seeming patterns. Such future studies will provide further insight into the dynamics of the factors that influenced the experiences and perceptions of participants. It would also be beneficial to attempt at drawing a stronger demarcation between the assessment of observed/actual occurrence of challenges, and the perceptions, even for respondents with experience in sustainable construction projects. While some of the challenges are most probably linked to contextual factors in South Africa, the appreciable agreement with extant literature sampled globally expands the generalisability beyond South Africa. It also demands the continuance of the study to higher levels of generalisability.

In furtherance of the current study, the following are suggested: A widening of the sample to a regional level, more detailed qualitative analysis with the use of relevant software packages, and the derivation of propositions, or hypotheses in future studies.

\section{References}

1. World Commission on Environment and Development, Our Common Future. G reat B ritain: Oxford University Press (1987), A vailable at: www.un-documents.net/ourcommon-future.pdf. [A ccessed: 17 A pril 2016]

2. S. M arcelino-Sádabaa, L.F. González-Jaenb, A. Pérez-Ezcurdiaa, U sing project management as a way to sustainability: From a comprehensive review, Journal of Cleaner Production 99:1-16 (2015)

3. F. Tessema, K. Taipale, J. B ethge, Sustainable Buildings and Construction in A frica, (2009), A vailable from: http://www.scpcentre.org/fileadmin/content/files/6_R esources/1_Publications_pdfs/28_Tessema_Taip ale_Bethge_2009_Sustainable_Building_and_Construction_in_Africa_en.pdf. [A čcessed: $\overline{1}$ A prī 2016]

4. J. Kivilä, M. Martinsuo, L. Vuorinen, Sustainable project management through project control in infrastructure projects, International Journal of Project Management 35(6):1167-1183 (2017)

5. W. Y u, S. Cheng, W. Ho, Y . Chang, M easuring the Sustainability of Construction Projects throughout Their Lifecycle: A Taiwan Lesson, Sustainability 10(6):2027 (2018)

6. R. Doskočil, B. Lacko, Risk M anagement and K nowledge M anagement as Critical Success Factors of Sustainability Projects, Sustainability 10(5):1438 (2018)

7. E.K. Zavadskas, J. Šaparauskas, J. Antucheviciene, Sustainability in Construction Engineering, Sustainability 10(7):2236 (2018)

8. P. Bocchini, D.M. Frangopol, T. U mmenhofer, T. Zinke, Resilience and sustainability of civil infrastructure: toward a unified approach, Journal of Infrastructure Systems, 20(2) (2014) 
9. A J. Silvius, J. V an der B rink, A. K ohler, The Impact of sustainability on project management, in $\mathrm{H}$. L inger, J. O wen (E ds), The Project as a Social System. A sia-Pacific Perspectives on Project M anagement (M onash U niversity Publishing, 2012)

10. A.J . Silvius, P.J Schipper, Sustainability in Project $M$ anagement Competencies: A nalysing the competence gap of project managers (2014), A vailable at: http://file.scirp.org/pdf/J HRSS_2014060310032620.pdf . [A ccessed 19 M ay 2016].

11. F. M isopoulos, R. M ichaelides, M.A. Salehuddin, V. M anthou, Z. M ichaelides, A ddressing Organisational Pressures as Drivers towards Sustainability in $M$ anufacturing Projects and Project M anagement M ethodologies, Sustainability 10(6):2098 (2018)

12. L.M. M artens, M.M. Carvalho, The challenge of introducing sustainability into project management function: multiple-case studies, Journal of Cleaner Production 117(20):29-40 (2016)

13. S. Martínez-Perales, I. Ortiz-Marcos, J.J. Ruiz, F.J. Lázaro, Using Certification as a Tool to Develop Sustainability in Project M anagement, Sustainability 10(5):1408 (2018)

14. G. Clinning, C. M arnewick, Incorporating sustainability into IT project management, South African Computer Journal 29(1) (2017)

15. L. Shen, V.W.Y. Tam, L. Gan, K. Y e, Z. Zhao, Improving Sustainability Performance for Public-Private-Partnership (PPP) Projects, Sustainability 8(3):289 (2016)

16. F. Ali, C. Boks, N. B ey, Design for Sustainability and Project $M$ anagement $L$ iterature - A Review, Procedia CIRP 48:28-33 (2016)

17. F.B. M arly, M . de Carvalho, E. de Senzi Zancul, Ecodesign in project management: a missing link for the integration of sustainability in product development? Journal of Cleaner Production 80(1):106-118 (2014)

18. S. B anihashemi, M.R. Hosseini, H. Golizadeh, S. Sankaran, Critical success factors (CSFs) for integration of sustainability into construction project management practices in devel oping countries, International Journal of Project Management 35(6):11031119 (2017)

19. M.A. Sánchez, Integrating sustainability issues into project management, Journal of Cleaner Production 96(1):319-330 (2015)

20. L. Larsson, J. Larsson, Sustainable Development in Project-B ased IndustriesSupporting the Realization of Explorative Innovation, Sustainability 10(3):683 (2018)

21. E. K aatz, D. R oot, P. B owen, B roadening project participation through a modified building sustainability assessment, Building Research \& Information 33(5):441-454 (2005)

22. B.G. Hwang, W.J. Ng, Project management knowledge and skills for green construction: Overcoming challenges, International Journal of Project Management (2013)

23. B.G. Hwang, W.J. Ng, Are Project Managers Ready for Green Construction? Challenges, Knowledge Areas, and Skills, in CIB World Building Congress, Queensland, A ustralia, 1-12 (2013)

24. B.G. Hwang, J.S. Tan, Green building project management: Obstacles and solutions for sustainable development, Sustainable development 335-349 (2012)

25. B.G. Hwang, W.J. Ng, Project management knowledge and skills for green construction; Overcoming challenges. International Journal of Project Management (2012) 
26. P.E. A kadiri, Understanding barriers affecting the sel ection of sustainable materials in building projects. Journal of Building Engineering 4:86-93 (2015)

27. The South A frican Bureau of Standards (n.d.) Giving you the quality edge, A vailable at: https://www.sabs.co.za/A bout-SA BS/index.asp [A ccessed: 7 J une 2018]

28. A.J.G. Silvius, M. K ampinga, S. Paniagua, H. M ooi, Considering sustainability in project management decision making: A $n$ investigation using Q -methodology, International Journal of Project Management 35(6):1133-1150 (2017) 